\title{
ASPECTS OF THE CHANDLER BILL TO AMEND THE BANKRUPTCY ACT
}

\author{
James ANgell Mclaughin*
}

\section{EQUITABLE DISTRIBUTION-A PRTMARY FUNCTION OF BANKRUPTCY}

POLITICAL history of bankruptcy in the United States serves unduly to emphasize the character of the subject in its aspect of debtor relief. Bankruptcy acts have always been enacted during or shortly after periods of depression. Times were none too good in the first Adams' administration. The panic of 1837 brought its quota of troubles. There was a natural let-down after the Civil War, the effects of which were not entirely obscured by the opening of the West. The hard times of the '9o's were the traditional hard times which first came to mind, until the more recent depression filled the picture.

The Act of $1867,{ }^{x}$ however, lasted longer than its predecessors of $1800^{2}$ and $184 \mathrm{I}^{3}$ and the Act of $1898^{4}$ has survived periods of recognized prosperity. This record of rising longevity is not accidental. Bankruptcy acts perform a function quite distinct from, though still consistent with, the function of debtor relief. It is elementary that bankruptcy constitutes one of the means for securing the equitable distribution of assets among creditors. It has the most potent sanctions among all the means of pursuing that end.5 In fact, it may be questioned whether the actual opera-

* Professor of Law, Harvard University Law School.

${ }_{14}$ Stat. 517 , repealed in 1878,20 Stat. 99.

22 Stat. 19 , repealed in 1803,2 Stat. 248.

35 Stat. 440 , repealed in 1843,5 Stat. $6 r_{4}$.

${ }^{4} 30$ Stat. 544 .

${ }^{5} \mathrm{Mr}$. Justice Cardozo has mentioned the immunity of insurance companies from bankruptcy as a consideration which should impress courts with the need of exercising comity with a view to minimizing the dismemberment of assets in races of diligence. See Clark v. Williard, 292 U.S. I12, I23 (x934). State statutes discouraging preferences are not necessarily superseded by the bankruptcy law. Stellwagen v. Clum, 245 U.S. 605 (IgI8) (applying $\$ \S$ IIro2-07, Ohio Gen. Code of I9I0). But many are superseded as integral parts of state bankruptcy laws. See Williston, The Effect of a National Bankruptcy Law upon State Laws, 22 Harv. L. Rev. 547 (Ig09). Although the common law permitting preferences in assignments for the benefit of creditors has been altered by statutes in many jurisdictions invalidating such preferences in whole or in part (see 4 Am. Jur. 402 (r93o); Manning v. Beck, r29 N.Y. r, 29 N.E. $9 \circ$ ( 1891 ) ), such statutes are by no means either universal or adequate. Some courts have even gone so far as to permit the debtor to set up his own little private debtor relief system by requiring a full release from the creditor, as a condition of a preferential part payment. Spaulding v. Strang, $3^{8}$ N.Y. 9 (I867); see 50 L.R.A. (n.s.) 714 D. (I9I4). A graphic idea of 
tion of our present bankruptcy law does not, over a large section of the country, relate more to equality of distribution than to debtor relief. ${ }^{6}$ In jurisdictions where the average citizen cannot be compelled to pay his debts anyway by reason of extravagant exemption laws there is little need of a bankruptcy law to serve the function of debtor relief.

Strangely enough, the potency of bankruptcy laws as a means of doing equity between creditors is very largely a modern development, due in large part to the intellect of a single man-Daniel Webster. Webster's

the relative insignificance of attempts to avoid preferences in receiverships may be obtained by comparing standard texts. Over $5 \%$ of Collier on Bankruptcy is devoted to $\S 60$ concerning preferences. The index alone of the fourth edition of Remington on Bankruptcy (I93I) contains 15 pages of entries regarding preferences, nearly 500 in all. About 150 additional entries occur under the closely related heading "Liens by Legal Proceedings Nullified by Bankruptcy." A single line suffices for the topic in the index to High on Receivers (Igro) although several additional entries relating to the distinct topic of priorities appear under the heading of "preference." Of the two cases cited in the text $(\$ \S 3 \mathrm{I} 4,320)$ one concerned preferences of corporate officers (Williams v. Turner, 63 Neb. 575,88 N.W. 668 (IgO2)), which are naturally peculiarly vulnerable. See Campbell, Preferences by Insolvent Corporations to Officers, Directors or Stockholders, 6r U. of Pa. L. Rev. I63 (Igr3). The only entry in the index of Clark on Receivers (2d ed. r929) is a cross reference to priorities, etc. Indeed the word in its offensive connotation is so unfamiliar in receivership that the term is frequently there employed to denote a valid priority. The activity under $\S$ I5 of the New York Stock Corporation Law has been exceptional. See Grossman, The Long Arm of the Trustee, 2 Am. Bkcy. Rev. 77 (1925).

${ }^{6}$ One of the conspicuous characteristics of the law of debtor and creditor in this country is the wide divergence between the extent of exemptions in different sections of the country. Exemptions in the Northeast are generally low. They are quite inadequate to insure the debtor the means of the most niggardly livelihood while his debts remain unpaid. In large portions of the trans-Mississippi regions exemptions are so high as to cast discredit on entire communities. Shortsighted local prejudice, failing to take into account that private credit will not be forthcoming except upon terms which discount the effects of exemption laws, has led to the enactment of laws which virtually make it an act of grace rather than a discharge of an enforcible legal duty for most debtors to pay their debts. High interest rates in the West have been the result not merely of scant resident capital. They have been, in a large part, the result of a legislative bias against the creditor, which has tended to retard the influx of private capital upon terms as favorable as those obtainable in the East. Many as have been the sins of Wall Street, the great open spaces have been on the wrong track when they assumed that the influx of distant capital was not to be encouraged. In the picturesque phrase of the cowboys, the regions really should be "tipped off" that some of their leaders have been "grazing on loco weed." The non-partisan league was not an economic success in the Dakotas. It remains to be seen how far government credit can long save communities or enterprises where private credit fears to tread.

The constitutional power of Congress clearly includes the power to establish a uniform law on the subject of bankruptcy, uniform with respect to the very vital element of exemptions. The political power of Congress has never approximated any such goal. For flagrant abuses of exemptions in bankruptcy, see Thacher and Garrison, Strengthening of Procedure in the Judicial System, Sen. Doc. 65, 72d Cong., Ist Sess. 2I-22 (1932). 
speech of June $5,1840,{ }^{7}$ led to the enactment of the first voluntary bankruptcy $\mathrm{law}^{8}$ and the first adequate statutory provision for the avoidance of preferences.9 One of his basic arguments has previously been summarized as follows:

That accommodation paper was the chief contemporary source of pyramided credit; that accommodation signatures were usually procured by arrangements for preferences which were indefeasible in the absence of a bankruptcy act; that such encouragement of lax credit practices led to hopeless financial entanglements which sounder practice would have arrested in a less destructive stage; and that consequently the enactment of a bankruptcy law, even a purely voluntary one, would operate to benefit the creditor as well as the debtor class by promoting a sounder credit structure..$^{\mathrm{x}}$

His stark and vigorous summary clinching this argument was modeled on The House That Jack Built:

.... this right of preference is the foundation on which the structure rests.

On the legal right or power of preference lies the promise of preference.

On the promise of preference lies endorsement.

On endorsement lies excessive and false credit.

On excessive and false credit lies over-trading. ${ }^{. x}$

This keen observation develops only one phase of a broader truth, viz., that while the interests of debtor and creditor are by no means identical, they have much in common. Sound credit practices tend to diminish credit losses. They not merely increase the supply of credit that is seeking outlet; they very much increase the confidence of creditors and their disposition to grant credit upon reasonable terms.

The enactment of bankruptcy legislation, however, has been powerfully and unduly influenced by uninstructed debtor psychology. It is only because the interests of debtor and creditor do have much in common that the Act of 1898 has served as well as it has. If one picks up at random a report in the '8o's, he is likely to be struck with the number of instances of litigation arising out of races of diligence between creditors. ${ }^{12}$ One

78 Cong. Globe, 26th Cong., ist Sess., app. 8I4.

${ }^{8}$ Act of $184 \mathrm{I}, 5$ Stat. 440 .

- Sec. 2, 5 Stat. 442 (184I). English bankruptcy law has suffered from the fact that statutes against preference date from $x 86 \mathrm{~g}$ in England. Prior attempts of the courts to cover the ground by invoking a doctrine of "fraudulent preferences" as a branch of the law of fraudulent conveyances has led to confusion. See Williston, Cases on Bankruptcy 245-47 (2d ed. I9I5).

ro See McLaughlin, Book Review, 49 Harv. L. Rev. 86r, 862 (x936).

iz 8 Cong. Globe, 26 th Cong., rst Sess., app. 814.

${ }^{22}$ Property students are most likely to remember an earlier case where a constable hid by the carriage house and won a game of barouche tag when another constable unlocked the door. Hollister v. Goodale, 8 Conn. 332 (I83I). 
would get the idea that sheriffs never slept. ${ }^{13}$ Races to make out papers must have been very hard on clerks in the days when typewriters were about as thinly distributed as airplanes are today. ${ }^{14}$ We may give credence to the remarks of experienced attorneys that federal bankruptcy legislation is here to stay, because under the pressure of modern business no one wants to go back to the rigors and injustices of "grab law." The fact that preferential transfers and preferential levies, shady assignments for the benefit of creditors and collusive umbrella receiverships can all be set aside in bankruptcy ${ }^{15}$ tends to diminish the zeal of the more aggressive creditors. Equity may "aid the vigilant, not him who slumbers on his rights," but although the bankruptcy court has no great reward for the snoozers, legislation, in the bankruptcy tradition, has borrowed from the chancellor the companion maxim that "equality is equity" with which to procure relief from rampant individualism.

Because bankruptcy legislation has always been bred by debtor relief out of depression, it is not surprising that the provisions of the existing law have been drafted and amended without receiving primary attention and without having commanded a high grade of drafting skill. The Chandler Bill is in large part devoted to curing the resultant defects of draftsmanship. Its more substantial features rest fundamentally upon the broad idea that the Bankruptcy Act may be employed as a vehicle of equitable distribution without substantially disturbing the present balance struck between debtor and creditor interests and without, in any way, impairing its character as a debtor relief act.

\section{UNATTEMPTED REFORMS}

Any thorough bankruptcy reform should involve a comprehensive reexamination of popular impressions concerning bankruptcy. Bankruptcy is thought by some to involve a "stigma." I6 Public opinion should stigmatize the man who lives high or gambles while his creditors whistle. It should regard with more sympathy than scorn the ambitious but com-

${ }^{2}$ In Albrecht v. Long, 25 Minn. I63 (1878), a sheriff suffered a lien to be displaced by waiting until 6:30 A.M. to levy an execution delivered to him at 2 o'clock the same morning.

$14 \mathrm{~A}$ crude machine patented in 1868 was the first to write at a speed substantially exceeding the pen. The 1874 Remington had certain standard modern features, but the first shift-key typewriter was offered on the market in 1878 . The first front stroke machine, solving the problem of visible writing, dates from 1897 . Before the ' 90 's touch typing was practiced "only by operators of exceptional skill." See Encyc. Brit., Typewriter (I4th ed. 1929).

I5 Sec. 3.

${ }^{16}$ See Thacher and Garrison, op. cit. supra note 6, at 68. Cf. "branding" as bankrupts, at 39. And see their proposed draft act entitled, Uniform System of Bankruptcy, Sen. Jud. Com. Print, 72d Cong., Ist Sess. 5, 27 (bottom pagination). 
mercially incompetent clerk or mechanic who unsuccessfully endeavors to become "his own boss" on borrowed money. There are also numerous cases of intelligent and honest individuals overcome by depression or other vis major. In any event the disgrace, if disgrace there be, has already been incurred upon insolvency. Such being the case, absolutely no stigma should be attached to submitting to the available machinery offered by the federal government for doing equity by the creditors. In this aspect it is quite clear that bankruptcy need not be "particularly offensive to the free and easy, but honest and true men of the West." It is not adapted to "squeeze them into the strait-jacket so befitting the madmen of Wall Street." "r7 This is a fortiori true, as long as the liberal exemptions of the West remain undisturbed beside the penurious exemptions of the East. Following out this line of thought, a thorough-going revision of the bankruptcy act, based upon sound economics and upon sound sociology, would contemplate various changes of our existing system left strictly untouched by the Chandler Bill. Some latitude might be left to local choice in the size of exemptions without countenancing the absurd variations which exist. The present impractical definition of insolvency computed upon some elusive fair value of frozen assets ${ }^{18}$ would yield to the business-like concept of inability to pay debts as they mature. At the very least, exempt assets would be excluded in determining solvency, even if, as one congressman is reported to have declared, such a change would render insolvent everyone in his district. It would recognize that acts of bankruptcy were obsolescent in the reign of Anne, when bankruptcy began to lose the character of a quasi-criminal instrumentality for coercing fraudulent debtors. ${ }^{19}$ As it is, the Chandler Bill very nearly contained a provision which would have substituted a simple test of insolvency and creditor choice for the complicated and expensive source of litigation which must now be encountered at the threshold of involuntary bankruptcy. ${ }^{20}$ Most of the foregoing reforms were not attempted because it was assumed that they were impossible as a matter of practical politics. This last change was excluded, however, chiefly on account of the congenital conservatism that so closely restricts the vision of any group of practicing lawyers.

The Chandler Bill has further omitted a thoroughgoing revision of the

${ }_{77}$ The quoted gems of debate were unearthed by Chas. Warren, Esq. See his Bankruptcy in U.S. History ${ }^{0} 4$ (1935). He attributes them to Rep. Paine of Wisconsin debating the Act of 1867 .

18 Sec. I (I5).

${ }^{19} 4$ Anne, c. I7 (I705). The modern form of bankruptcy dating from $x 84 \mathrm{I}$ in this country is also about roo years old in England. See Williston op. cit. supra note 9, at 4 .

${ }^{20}$ Sec. 3. 
basic structure of bankruptcy administration for reasons relating to the constitution of the so-called National Bankruptcy Conference, which has evolved the Bill. It is a Conference not only primarily composed of practical men. Several of its most active and industrious members are full time referees in urban districts. The character and ability of these individuals is such as to give even the academic theorist cause to pause before suggesting that another system might be preferable. It is, nevertheless, submitted that the fee system is extremely difficult to defend. In a journal prepared under the auspices of a member of the Association of American Law Schools, it is unnecessary to elaborate the further disadvantages of part-time work in an office requiring first rate attention and intellectual ability. ${ }^{2 x}$ The geographical distribution of referees is determined by considerations dating from horse and buggy days. In some districts there is not enough work to attract competent men. In the large cities, on the other hand, the judges have gone to the limit of the law in passing responsibility on to referees, and a few of these officials reap almost princely incomes. There is loss of time and efficiency in having a district judge hurriedly review something that has already received the painstaking attention of a competent lawyer acting in a judicial capacity. The conclusion is that referees ought to be greatly reduced in number and turned into bankruptcy courts responsible directly to the circuit court of appeals. This would involve adequate salaries, clerical assistance and court rooms, and power to commit for contempt. Opinions and tastes may differ on the question of robes. In any event, external conditions in the bankruptcy court should be designed with a view to promoting respect for the court as well as promoting its business efficiency.

Other important changes in bankruptcy administration which should at some time receive the attention of Congress are also outside the scope of this Bill; for example, the proposal of Messrs. Thacher and Garrison to have official examination and administration of small estates to supplant administration by a trustee elected by more or less indifferent creditors. ${ }^{22}$ The fear that the inefficiencies of private enterprise, as represented by lawyers and credit men in such cases, might be eclipsed by the inefficiencies and wastes of bureaucracy was strong among the practical members of the National Bankruptcy Conference. The demoralizing effect

${ }^{2 x}$ An abbreviated and expurgated record of a warm debate at the $1924 \cdot$ meeting, when the requirements concerning full time teachers were raised, appears in 5 Am. L. School Rev. 485-89 (1925). Cf. Testimony of L. K. Garrison concerning the referees. Hearings on S. 3866, 72 Cong., Ist Sess., pt. 2, p. $309 \mathrm{ff}$.

${ }^{22}$ See the Hastings Bill (S. 3866, 72d Cong. Ist. Sess.), $\S \S 44,45,53$; Garrison, $o p$. cit. supra note 21 , at 309 ff, 427 . 
upon business practices when creditors permit fraudulent "no asset" cases to go by default has probably been insufficiently appreciated, although the Chandler Bill encourages the use of existing officials to combat the situation. ${ }^{23}$

\section{THE ORIGIN OF THE CHANDLER BILL}

The ground has been cleared for an exposition of the Chandler Bill by discussing what it is not. An understanding of what it is may be promoted by a further description of its parentage. The Act of 1898 was loosely drafted. Inapplicable language imported unwittingly from the Act of $I 867^{24}$ and inconsistent overlapping provisions included by an easygoing conference between the Houses of Congress ${ }^{25}$ are only flagrant indications of the careless fashion in which the law was thrown together at that time. Some improvements were made in $1903^{26}$ and in $19 \mathrm{IO}^{27}$ and minor amendments were made at other times. More changes, chiefly designed to minimize fraud and to expedite administration, were introduced in $1926 .{ }^{28}$ They were the result of cooperation between the American Bar Association Committee on Commercial Law and Bankruptcy, the Commercial Law League of America and the National Association of Credit Men.9 Academic criticism of the form of these amendments accompanied by concrete suggestions for remedying serious defects relating to equal distribution in the existing substantive law of bankruptcy ${ }^{30}$ met, in 1927 , the whole-hearted approval of the Bar Association Committee ${ }^{3 \mathrm{x}}$ and of the newly formed National Association of Referees in Bankruptcy. ${ }^{32}$ Influential individuals in the Commercial Law League shared the same view. But the Bar Association Committee fell for several years into the hands of conservatives who saw no reason to disturb the law that had served for thirty years and so to deprive us of the supposed benefits of thirty years of decisions. 33 Congressmen said, in substance, "we have just finished fixing up your Bankruptcy Act" and the roaring late '2o's was not a time when popular attention could be focused on bankruptcy. If-but

${ }^{23}$ See Thacher and Garrison, op. cit. supra note 6, at 13-25.

${ }^{24} \mathrm{Sec} .67(\mathrm{e})$ refers to the assignee in bankruptcy who does not exist by that name.

${ }^{25} \mathrm{Sec} .67$ (c) and (f). See $I_{n 2} r e$ Richards, 96 Fed. 935 (C.C.A. 7 th 1899 ); 3 I Cong. Rec. $6428-29(x 898)$.

${ }^{\infty}{ }_{32}$ Stat. 797. ${ }^{27} 3^{6}$ Stat. 838 . ${ }^{28} 44$ Stat. 662 .

${ }^{29} 5$ r Rep. Am. Bar Ass'n 472 ff. (r926).

${ }^{30}$ McLaughlin, Amendment of the Bankruptcy Act, 40 Harv. L. Rev. 34I, 583 (1927).

${ }^{32} 52$ Rep. Am. Bar Ass'n 258 (1927).

${ }^{32}$ See 2 J. Nat'l Ass'n Ref. in Bkcy. 6I (rg27).

${ }^{33} 53$ Rep. Am. Bar Ass'n 388 (1928). 
to proceed with the narrative. The depression again directed attention to the debtor-relief aspect of bankruptcy, but a cross current set the professor's proposals afloat. The Donovan Investigation of bankruptcy frauds in New York City supplemented by an investigation of the United States Department of Commerce in cooperation with the Yale Law School ${ }^{34}$ furnished the main impetus to bills introduced toward the end of the Hoover Administration. ${ }^{35}$ Solicitor General Thacher and his aide, Mr. Garrison, were much interested in revising bankruptcy administration from the point of view of curing defects due to creditor inertia, particularly in small cases. They were also concerned in affording an opportunity for debtors to claim the advantages of the federal bankruptcy power while avoiding the "stigma" of bankruptcy..$^{36}$ Bankruptcy lawyers, credit men and referees, representing preponderant opinion in the organizations mentioned above, considered these proposals impractical. The opinion prevailed that the best way to meet the Thacher proposals in Congress was to be prepared with an alternative positive program. The administration lawyers politely recognized the scholarly character of the proposals made with reference to equitable distribution, but showed no interest in incorporating them into administration bills. In fact the proposals affecting administration which interested the solicitor general's office operated in a field so distinct from that encompassed by the substantive law proposals that there was no substantial contact between the exponents of the two lines of thought. The lawyers and referees, however, were interested in the substantive law proposals, not merely as affording a tangible alternative to the solicitor general's program but also as having intrinsic merit warranting their careful study and promulgation in the most practical form. The result was what later came to be styled the National Bankruptcy Conference. Two referees, four lawyers, and one

34 "In I929 a thorough investigation of the bankruptcy administration in the southern district of New York was concluded before the district court by counsel representing the three bar associations of New York and Bronx Counties. The report of counsel to the associations, William J. Donovan, summarized the evils disclosed, recommended important changes .... and indicated the advisability of further investigation..... (House Judiciary Committee Print, 7Ist Cong., 3d Sess.) At about the same time the Department of Commerce conducted a series of studies of the causes of bankruptcies, at first independently and later in cooperation with Yale Law School, which extended the inquiry into the administrative field." See Thacher and Garrison, op. cit. supra note 6, at 4 .

35 Chiefly S. 3866, 72d Cong., Ist Sess. (the "Hastings Bill"). H. R. 9968, introduced by Mr. Michener in the same session, was identical. Mr. Hastings also introduced other bills concerning moritoria for individuals and corporate reorganizations. See S. 492I, S. 4923. See also $H$. R. I4240 and H. R. I4359 for different measures pressed by various interests at this time.

${ }^{36}$ See note $x 6$ supra. 
full time law teacher met at a lawyer's home in Wellesley, Mass., one week end in June, I932, and, pursuant to a declared intention to draft all necessary amendments to the Act by Monday next, spent three days arguing about the definitions in section $\mathrm{I}$. Some of the members of this group were amused at the idea that anything more than a broad discussion of principles could be accomplished in such a limited time, but none anticipated the volume of intensive work, negotiation, and correspondence that lay ahead. ${ }^{37}$ Such anticipation would probably have deterred even the most enthusiastic from committing themselves to the investment of time and energy that was to be required. The Conference later grew to more than forty members. The Bar Association, Referees', Credit Men's and Commercial Lawyers' Associations each undertook a small contribution to pay clerical and printing expenses. Members of the appropriate committees of these organizations were made the basis of the Conference. Additional members were added from time to time as particular interest or particular competence appeared or as particular subject matter called for the introduction of specialized talent, as in the case of corporate reorganization, stockbrokerage bankruptcy, or real property arrangements by unincorporated persons. Members occasionally added for reasons of diplomacy or promotion did not seriously impair the work. Aged conservatives impressed with the perfections of the Act of 1898 died, withdrew from active participation or gradually acquired an almost human elasticity of mind. Between the ten or more meetings of the Conference which have usually been attended by from 15 to 25 members a lively correspondence has been carried on by the more active members. A drafting committee of 5 to Io has had more frequent meetings. Collaboration between even smaller groups involving occasional personal meetings has contributed to the evolution of the bulk of the actual language. The detailed work of polishing the form of all proposals has naturally fallen into very few hands by a process of informal natural selection. ${ }^{38}$

The Chandler Bill itself ${ }^{39}$ was first introduced into the 74 th Congress

37 The writer's Conference correspondence for January I937 exceeded 400 pages.

${ }^{38}$ Although this description of this operation of the Conference has avoided giving prominence to names of individuals, no description of the work of the Conference would be adequate without calling attention to the extraordinary contributions of a few members. The superb tact and tireless leadership of Chairman King have been required to carry such a loose organization through nearly to its goal. The superb draftsmanship and fabulous industry of Jacob Weinstein of the Philadelphia Bar have raised the standard of form to a point rarely approached by American legislative proposals. In the latter part of the Conference's work many flaws have been detected and cured by the keen and patient detailed criticism of Referee Adair of Pittsburgh.

39 H. R. 12889, 74th Cong., 2d Sess. 
by the Representative of that name on the Subcommittee on Bankruptcy and Reorganization of the Committee on the Judiciary of the House of Representatives. Mr. Chandler, while being most particular to disclaim the detailed authorship of the Bill, is a Congressman with experience in bankruptcy and credit matters who understands and favors the purposes of the Bill. He has been keeping in touch with the Conference and has made various suggestions of procedure with reference to the promotion of the Bill as well as with reference to matters of substantive content. A revision of the Bill to be introduced into the $75^{\text {th }}$ Congress is at present awaiting a revision of the corporate reorganization sections. The Securities and Exchange Commission has recognized the Conference as a body with whom it may cooperate in procuring a revision of the corporate reorganization sections designed to minimize abuses of power on the part of committees representing security holders, and further to formulate additional proposals growing out of the Commission's investigation of reorganizations. ${ }^{40}$

The number of points covered by amendments in the Chandler Bill precludes anything approaching a complete discussion. They cannot be precisely enumerated because of the inevitable questions of casuistry involved in determining units. By any count, the number is up in the hundreds. Consequently, this discussion will encompass only a few of the more important of those amendments with which the writer has been particularly concerned. Without passing any judgment concerning the relative importance of most of the amendments primarily promoted by other conferees, it may be remarked in passing that some such provisions are of the greatest importance. The corporate reorganization and individual extension sections of the law have been much more clearly stated and better coordinated with the composition provisions. ${ }^{4}$ The further revision to which the corporate reorganization provisions are being subjected will unquestionably tend to protect the individual investor from exploitation by reorganization committees. Much nebulosity has been dissipated by a restatement of the partnership section..$^{42}$ The list could be

${ }^{40}$ At present writing it is uncertain how much resistance the Commission's proposals will encounter within the Conference or how much additional time will be required to formulate the needed provisions. The opinion may be ventured that preponderant opinion within the Conference will support the recommendations of the Commission. A joint product should improve the political chances of the entire Bill. See p. 402 infra. Whether considerations of time or other unforeseen developments will lead to a severance of the corporate reorganization proposals remains to be seen.

${ }^{4}$ Sec. I2. And see note 49 infra.

4 Sec. 5. The partnership has been treated consistently as distinct from its members, thus following the line of thought suggested by that in Liberty Nat'l Bank of Roanoke v. Bear, 
lengthened, but not without departing from a resolution to concentrate upon a manageable portion of the field.

\section{CHANGES AFFECTING DEBTOR'S INTERESTS}

On the whole it is apparent that, while the Conference tends to represent creditor interests, it is by no means a group seeking narrow ends in conflict with the public interest. The protection and relief afforded to the honest debtor is to be in no way impaired. On the contrary the debtor is to be newly protected in such matters as failure to obtain a discharge due to the neglect of his attorney to make timely application. ${ }^{43}$ This is achieved by the very simple device of dispensing with the necessity of a separate application for a discharge, the adjudication being permitted to serve that function. ${ }^{44}$ Provisions making contingent claims provable and hence dischargeable can have only favorable effects on debtors' interests. Amendments to this effect, favored and promoted by members of the Conference, ${ }^{45}$ have already been enacted with particular reference to executory contracts and future rent. ${ }^{46}$ The present Bill improves the form and the generality of those provisions, rounding out the expression of statutory policy to relieve the debtor of all his existing entanglements and to broaden the field of equitable distribution as far as possible. ${ }^{47}$ At present the Conference has under consideration a proposal to make all tort claims provable. Claims against the after-acquired property of bankrupt corporations are manifestly illusory and there is no justification for not permitting all tort creditors to prove against corporate bankrupts. A r934 amendment authorizing proof of judgments on actions for negli-

276 U.S. $21_{5}$ (rg28); and rejecting that in Francis v. McNeal, 228 U.S. 695 (rgr3). Provision is made for a petition by one partner "on behalf of" the firm. Such a petition must allege insolvency. This in substance, though not in form, provides for involuntary bankruptcy of the firm at the suit of less than a majority of the members, insolvency being the only statutory condition precedent to bankruptcy (i.e., the only act of bankruptcy). This supplies the need left by Meek v. Centre County Banking Co., 268 U.S. 426 (I925) when it knocked out G. O. no. 8 .

${ }_{43}$ Twenty-three per cent of non-corporate bankrupts failed to apply for a discharge in the 3o months ending Mar. 1 , 1929. See Thacher \& Garrison, op. cit. sicpra note 6, at 204.

44 By amendment to $\$ \mathrm{I}_{4}(\mathrm{a})$.

45 See McLaughlin, op. cit. supra note 30, at 590. Conferees Hunt, Adair and Weinstein have also contributed to the expansion of $\S 6_{3}$ (a) relating to provable claims.

${ }^{46}$ Bankruptcy Act $\$ \S 77 \mathrm{~B}$ (b) 10, 63(a) 7, Act of June 7, I934, c. 424, $\$ \S$ I, 4, 48 Stat. 9I5, 923.

${ }^{47} \mathrm{Sec} .63(\mathrm{a})$ in the Bill at present includes nine clauses and two provisos. The new matter includes a general clause expressly authorizing the proof of contingent contractual liabilities. Following ancient practice the courts will not apply this provision where impracticable to value the claim. See McLaughlin, loc. cit. supra note 45 . 
gence instituted prior to the bankruptcy ${ }^{48}$ introduced indefensible distinctions. There is no reason why the victim of an intentional tort should stand worse than the victim of negligence and there is no point in requiring a race of diligence between the tort claimant and the bankrupt to see who can file his papers first. These considerations suggest the incorporation of a broad provision for the proof of all tort claims, a further boon to the debtor.

No drastic changes are made in the provisions designed to protect creditors against fraudulent debtors..$^{49}$ Although fraud is doubtless still too prevalent, the statutory amendments made in $1926^{50}$ did not leave much to be done along the conservative lines favored by the Conference. It was not only desired to avoid the mixed blessings of additional administrative personnel. Provisions for adequate judicial control through the medium of suspended or conditional discharges ${ }^{5 x}$ would be likely to encounter political opposition which might better be encountered at a later date after persuading Congress to achieve the unquestionable advance marked by the Chandler Bill in its disposition of other problems. Of course, the battle against fraud must ever be fought in the field by credit men, better business bureaus, bar associations and the like.

To a very minor extent, the title of the trustee has been extended at the expense of the debtor, but this only applies to debtors acquiring property by inheritance or survivorship during the bankruptcy proceedings.52 Property acquired in such a manner stands on a very different basis from the bankrupt's subsequent earnings. It is in the nature of a windfall having no relation to his normal budget. It seems unnecessary to the protection of the honest but unfortunate debtor to allow the spendthrift to obtain immunity in bankruptcy while his wealthy ancestor is on the death

$4^{8}$ The Act of June 7, I934 inserting $\S 63$ (a) $6 \frac{1}{2}$.

19 Sec. I2, I is a combination of present $\$ \$ . I 2$ and 74 . Its careful spelling out of procedure for proposing, examining and approving arrangements involving either secured or unsecured creditors or both should have the incidental effect of reducing the attractiveness of compositions as a means for achieving immunity without adequate investigation. Attempt is made to deal with the fraudulent "no asset" case, in a new paragraph, $\mathrm{I}_{4}(\mathrm{~d})$, which makes it the duty of the United States Attorney, when requested by the court (which means usually the referee as a practical matter) to investigate and to oppose the discharge, if satisfied that probable grounds exist. The weakness here lies in the fact that nothing may happen in many fraudulent cases to arouse the referee's suspicion or the District Attorney's energy. Sec. $1_{4}$ (d) falls short of the Thacher-Garrison proposals, which were designed to provide a thorough examination in all cases. By amendment to $\& x_{4}($ b) 5 the benefit of a composition is put on a par with a discharge in that either operates as a ground for objection to another discharge or composition within 6 years. A few technical points have been covered concerning crimes in $\$ 29$.

${ }^{50} 44$ Stat. 662. ${ }^{5 x}$ See Thacher \& Garrison, op. cit. supra note 6, at 99-Io3.

52 Sec. 70 (a) $7-9$. 
bed. There is no reason why tenancies by the entirety, founded on the obsolete conception of the unity of the spouses, ${ }^{53}$ should make a bankrupt's interest inaccessible, if he acquires the whole property upon the death of his spouse during the proceedings. Justice would suggest the more radical step of providing that bankruptcy should require the severance of such a tenancy, but the Bill stops with the much less substantial change above described. A few changes of this sort, where the debtor's interest is weighed in the balance and found wanting, constitute, in the aggregate, such a small portion of the subject matter of the Bill and constitute such a negligible modification of the extraordinary leniency shown debtors by the combination of the bankruptcy law and the exemption laws in those regions most controlled by debtor psychology, that unreasonable political opposition is scarcely to be expected on that account. If such opposition were encountered, these provisions could readily be dropped from the Bill without substantially impairing its usefulness.

\section{EQUITABLE DISTRIBUTION-THE TRUSTEE'S TITLE}

We come, then, to concentrate our attention upon portions of the substantive law of bankruptcy directed to the adjustment of the rights of creditors between one another and having no direct relation to conflict between creditor and debtor interests. Performing the function of doing equity between creditors is primarily a problem of collecting assets. It is comparatively easy to make an equitable distribution of whatever the trustee has to distribute. ${ }^{54}$ Valid transfers by the bankrupt must be respected, as well those creating liens as those passing title. Thus, for a very crude first approximation, the trustee may be regarded as stepping into the debtor's shoes. In some instances, due to the technicalities of property law, such as the above mentioned tenancy by the entirety, which exists in some states, the trustee cannot become fully the assignee of all the debtor's rights. Most of these limitations upon the trustee's title, however, will operate only occasionally and are of relatively trivial importance. The only substantial unnecessary limitation upon the trustee's successorship is found in the recognition of state exemption laws, already sufficiently discussed.

The trustee's title is in an unsatisfactory state, however, with reference

s3 See Note, Tenancy by the Entirety and the New York Transfer Tax, 29 Harv. L. Rev. 201 (I9I5).

54 Showings of dividends to creditors by adjustment bureaus administering insolvents? estates greatly exceeding dividends in bankruptcy are to be explained chiefly by the fact that only the tough cases reach the bankruptcy courts. Anybody can sell marketable assets and pass out checks. 
to the time when it accrues. The Act of 1898 states that he gets title as of the adjudication, ${ }^{55}$ but makes no express provision for the general protection of the bankrupt estate in the interim ${ }^{56}$ between the petition and the adjudication. This gap has necessarily been supplied by the courts, but in an unsystematic manner, which at times seems almost disingenuous. The Supreme Court in Mueller v. Nugent57 declared that "a petition in bankruptcy is a caveat to all the world, and in effect an attachment and injunction." This statement may seem on its face to be a potent source of litigation. Any suspicion to this effect is not diminished by the fact that it has been cited over thirty times by the Supreme Court and more than three hundred times by the lower federal courts..$^{8}$ Few, if any, bankruptcy cases have been cited as frequently, and indeed there cannot be many Twentieth Century cases in any field which have been more frequently so noticed. The above quoted dictum has been the life of the entire party. It has been entertained in almost every conceivable way, being applied according to its face value or distinguished as convenience or common sense dictates. Mr. Justice Holmes said the statement "must be taken with reference to the facts before the court and not as applicable to all intents and purposes." He cited with approval59 a passage where Sanborn, J., referred to "later decisions of the Supreme Court adjudging that this statement applies only to parties who have no substantial claim of a lien upon or a title to the property of the bankrupt, and that, against those who have such claims .... when the petition .... is filed, .... its filing is neither a caveat or an attachment and that it creates no lien. ... " ${ }^{\prime 60}$ Circuit Judge Ward, upholding a decision in favor of a bank honoring a check of the bankrupt between the petition and the adjudication, said, "whatever else the remark may mean, it cannot mean, in contradiction to the express provision of the Act, that the title of the bankrupt shall vest in the trustee as of the time of filing of the petition."6r However, even this apparently safe statement is far from the truth, for it

ss Sec. $70(\mathrm{a})$, introductory clause.

${ }^{6}$ Thus, while $\$ 60$ specifically defines a preference to include a transfer during this interval, there is no such provision with reference to fraudulent conveyances or liens by legal proceedings.

57 I84 U.S. $1, I_{4}$ (I902).

${ }^{8}$ Thirty-two Supreme Court decisions are given down to and including the November 1936 issue of Shepard's Citations. (One of them, 225 U.S. 625, should be 225 U.S. 695.) $3^{13}$ citations to the various series of the Federal Report System appear.

59 Jones v. Springer, 226 U.S. I48, I55 (I9I2).

6o In re Rathman, I83 Fed. 913, 924-25 (C.C.A. 8th Igro).

6x In re Zotti, I86 Fed. 84, 86 (C.C.A. 2d I9Ir). 
is stated that "broadly speaking the adjudication when made relates back to the commencement of bankruptcy proceedings." ${ }^{262}$ The fact is that the theory of a date of cleavage as of which the assets and liabilities of the estate are adjusted is almost indispensable to the conduct of bankruptcy administration. The Bankruptcy Act of 1898 is clearly constructed with primary reference to the filing of the petition as the date of cleavage. As we have seen, the failure to prohibit transactions detrimental to the estate after the petition suggests the assumption that the property is in custodia legis, at least "for certain purposes," after the petition. Furthermore, claims are made provable or not depending upon their existence in some form at the date of the petition. ${ }^{63}$ Apart from unimportant exceptions proposed by the Chandler Bill the bankrupt has unqualified title to the property he acquires after the date of the petition. Upon the whole, it seems fair to say that, whatever this much discussed dictum may mean, the Bankruptcy Act of $I 898$ really means precisely that "the title of the bankrupt shall vest in the trustee at the time of the petition," "in contradiction to the express provision" found in one clause of the Act. ${ }^{64}$

The only trouble with this theory is that it discloses a very serious gap in the Act of 1898 in that there is no reference to transactions to be protected after the date of the petition. The simplest solution is to give the trustee title from the petition and expressly provide for the type of subsequent transactions to be protected. The Chandler Bill endeavors to give the courts such a clear statutory basis (in lieu of a crazy quilt of contradictory judicial statements) with which to continue to work out a reasonable system for balancing the conflicting interests during the term between the commencement of the proceedings and the commencement of the actual administration when the receiver or trustee moves to reduce the assets to his possession. The present draft of the Bill ${ }^{65}$ is probably inadequate to protect parties not technically bona fide purchasers who deal with the bankrupt in the ordinary course of business during this interval without impairing the estate. ${ }^{66}$ There is some question whether it is flexible enough to provide for such matters as state court action to liquidate perishable property taken without notice of the bankruptcy

${ }^{62}$ Per curiam, Citizens' Union National Bank v. Johnson, 286 Fed. 527, 528 (C.C.A. 6 th I923).

${ }^{63}$ For modifications of the theory with reference to contingent claims and assets see pp. 379,380 supra.

${ }^{6} \mathrm{Sec}$. 7o(a) introductory clause. ${ }_{65} \mathrm{Sec} .70(\mathrm{~d})$.

${ }^{66}$ Such as banks honoring the bankrupt's checks. In re Zotti, I86 Fed. 84 (C.C.A. 2d I9II); Citizens' Union Nat'I Bank v. Johnson, 286 Fed. 527 (C.C.A. 6th I923); In re Retail Stores Delivery Corp., II F. Supp. $65^{8}$ (N.Y. I935). 
proceedings. These questions will be presented to the Conference shortly. Dealings with the bankrupt prior to the adjudication involve a policy against intimidating those who transact business with a person against whom a petition has been erroneously filed. This consideration is missing in the interval between the adjudication and the qualification and action of the trustee, but a codification of existing law would provide a limited degree of protection in some cases even during the later interval. ${ }^{67}$

The approximation of identifying the trustee's rights with those of a general successor to a bankrupt is most inaccurate, however, because it neglects the extremely important topic of voidable transactions. As Webster said, the threat of having securities invalidated is a strong influence restricting the extension of unsound credit based on promises of preferences. Such threats, however, cannot operate efficiently in terrorem only. Actual avoidance must frequently take place in order that this influence may be maintained. Furthermore, the setting aside of inequitable advantages is, itself, of the very essence of equitable distribution.

Voidable transactions consist chiefly of fraudulent conveyances, preferences, and liens obtained by legal proceedings. ${ }^{68}$

\section{FRAUDULENT CONVEYANCES}

Fraudulent conveyances have, on the whole, been fairly amenable to attack under the existing law. Such conveyances are so manifestly in the teeth of a bankruptcy law that the courts would avoid them under any statute that left a way open for such action. Nevertheless, there is room for improvement. The present fraudulent conveyance provisions consist in substance merely of a skeletonized federal statute of Elizabeth plus a broad authorization to the trustee to avail himself of remedies under state law. The state laws have generally served pretty well. The most serious obstacles to recovering fraudulent conveyances relate to discovery and like matters of evidence. Nevertheless, there is no reason why, in the process of revising the Bankruptcy Act, steps should not be taken to develop the fraudulent conveyance provisions so as to achieve a better correlation with the rest of the Statute and so as to take advantage of the best thought of the time concerning the substantive law. Accordingly the proposed revision deals expressly with time limitations upon attack by the trustee in bankruptcy on fraudulent conveyances, with particular reference to the application of recording acts in this connection, thus developing with reference to fraudulent conveyances a subject matter

${ }_{67}$ Jones V. Springer, 226 U.S. I48 (I9I2).

${ }^{68}$ Liens obtained bÿ legal proceedings, although an important topic, is not separately developed in this article. See, however, pp. 389-9I infra. 
developed in the Act of 1898 only with reference to preferences and then inadequately developed, as we shall see. For the purposes of claiming the benefits of recording acts the trustee is in effect given the status of a bona fide purchaser. ${ }^{69}$ Where the trustee elects to rely upon state law he may still obtain the benefit of state statutes of limitation, which in most cases greatly exceed the brief period of four months during which the federal law insists upon the defeasibility of such transactions. The trustee in bankruptcy may, however, occasionally elect to rely upon the federal law for reasons to be mentioned later.

From the point of view of new language, one of the most radical innovations of the Bill is the interweaving into the federal law of the substance of the Uniform Fraudulent Conveyance Act. ${ }^{70}$ Moreover this proposal, while involving no drastic practical readjustments, has theoretical significance of considerable importance. A theory has been fashionable among bankruptcy practitioners that the defeasibility of a conveyance alleged to be fraudulent is solely a question of state law. It is abundantly clear on principle, however, that the Constitution, in giving Congress the power to establish uniform laws on the subject of bankruptcies, ${ }^{7 x}$ is giving Congress power to pass a uniform law on the subject of the equitable distribution of an insolvent's assets. Prior to 1787 the distribution aspect of bankruptcy was prominent, ${ }^{72}$ and that aspect has been an integral part of all bankruptcy legislation. ${ }^{73}$ Doing equity without determining the conditions upon which the trustee may collect the assets which the bankrupt is attempting to dissipate involves a fatuity and a frustration quite unnecessary under the Constitution and under the Act of I898. Paragraph 67 (e) of the latter clearly provides first for a federal law of fraudulent conveyances and then proceeds to give the trustee the additional right to take advantage of state laws directed towards a similar end. The first sentence invalidates transfers "with the intent.... (on the part of the debtor) to hinder, delay or defraud his creditors." The quoted words (sometimes transposed in order) occur repeatedly in the statute of I3 Eliz. c. 5 (I 57O) and the identical words have been repeated in judicial decisions and have been widely enacted in statutes in this country. The statute of I3 Eliz., having been in force prior to the colonization of this country, was clearly eligible to become what we Americans, with a flair

${ }^{69}$ In $\$ \S 60(\mathrm{a}), 67$ (d) 5 ; and see $\$ \S 3(\mathrm{~b}), 70(\mathrm{c})$.

${ }^{70}$ Sec. 67 (d)

${ }^{2}$ U.S. Const., Art. I, $\S 8$, cl. 4.

r See Williston, Cases on Bankruptcy I-6 (2d ed. I9I5). This truth is of world wide application.

${ }^{73}$ See Travers, Faillite et Institutions Analogues I3 (I935); McLaughlin, Book Review, 50 Harv. L. Rev. 379, 380 (1936). 
for Irish bulls, are accustomed to call "a common law statute." Not only was it accepted without question as such in matter of substance, but the innumerable repetitions of the same linguistic formula also invested it with the magic properties which we lawyers, as Medicine Men, attribute to "words of art." In short, when Congress refers to conveyances with "intent to hinder, delay and defraud creditors," it is using a phrase which is unquestionably to be interpreted with reference to legal learning. Legal learning in this instance points unequivocally to the statute of Elizabeth and to the generally prevailing concepts of justice that have been developed thereunder. The first sentence of section 67 (e) is thus clearly a declaration that the accepted general jurisprudence of fraudulent conveyance shall be available to the trustee. This is not a legal proposition based upon such debatable foundations as the doctrine of Swift v. Tyson, ${ }^{74}$ that federal judges are free to enforce their own ideas of what the judgemade law ought to be where state law seems to them incorrect in matters of general commercial concern. The proposition is simply that when Congress, in the exercise of a power clearly and expressly conferred upon it by the Constitution, passes a statute in words that have received a generally accepted meaning as a matter of legal learning tracing back to the common inheritance of all American lawyers, such words shall be interpreted as having a meaning uniform throughout the United States based upon such learning and upon the general development of American judge-made law pursuant to that tradition. The Supreme Court flatly decided under the Bankruptcy Act of 1867 that the provisions of that statute would control over a minority rule of fraudulent conveyances in force in the state where a transfer took place..$^{75}$ Strangely enough, the question does not appear to have been litigated in any reported cases arising under the Act of 1898 . Not only have bankruptcy lawyers been predominantly lawyers of local training, but federal judges have naturally been recruited from the bars in the localities in which they sit. It is no reflection upon the learning of these judges that they have submitted to the decisions of questions under 67 (e) primarily with reference to local cases. In a great majority of instances, of course, the difficult questions of fraudulent conveyance trials are questions of fact. In many more cases the trustee has relied upon state law anyway. In most of the remaining cases differences between the local law and the general law, if perceptible, were not material.

The concessions just made should not lead to the conclusion that changes made in the Chandler Bill are gratuitous and pointless interfer-

74 I6 Pet. (U.S.) I (I842).

75 Warren v. Moody, I22 U.S. I32 (I887). 
ences with existing practice. An examination of the application of the Uniform Fraudulent Conveyance Act up to and including the year 1932, which attempted to be an exhaustive examination of cases, definitely indicated that that Act was operating beneficially. ${ }^{76}$ The bar of some states had been surprisingly slow to recognize the fact of the enactment of the Statute. Substantially no other blemishes appeared upon the record. Local variations both in the substantive law and in the procedure relating to fraudulent conveyances appear to have been chiefly due to accidental causes such as the type of facts presented in the leading cases in different jurisdictions and such as which side had the better lawyer. In any event, there was very little evidence of judges insisting on adhering to local peculiarities in defiance to the policy of uniformity declared in the Act. ${ }^{77}$ In some cases it was necessary for appellate courts to assist in the education of the chancellors. ${ }^{78}$ The Act met little resistance in jurisdictions where it substantially altered the law, probably because the provisions of the new law were recognized as being definitely sound in principle. While endeavoring to remove both procedural and substantive technicalities inuring to the benefit of the debtor who was unduly optimistic or generous at the expense of his creditors, the uniform law simultaneously abrogates unduly zealous rules for the protection of the creditor which unnecessarily impair the security of transactions with "indebted persons."79 The movement towards uniform legislation is so worthy in purpose and the obstacles encountered in procuring the enactment of such legislation are so serious that it is surprising that the federal power has so long been neglected as a means for promoting this end. The Advisory Committee on the Rules for Civil Procedure appointed by the Supreme Court of the United States has just approved a proposal to incorporate into the new federal rules the most important procedural reform embodied in the Uniform Fraudulent Conveyance Act. ${ }^{80}$ Since the Uniform Fraudu-

$7^{6}$ McLaughlin, Application of the Uniform Fraudulent Conveyance Act, 46 Harv. L. Rev. 404 (1933).

77 Id. at $45^{2}$. $\quad 7^{8} I d$. at 445, n. 208.

79 Rules tracing back to Chancellor Kent and to days of comparatively restricted use of credit (see Reade v. Livingston, 3 Johns. Ch. (N.Y.) $48 \mathrm{I}$ (18I8)) introduced needless kinks into the law of several jurisdictions. See McLaughlin, op. cit. supra note 76, at 407-9.

${ }^{80}$ The new provision expressly declares that " a fraudulent conveyance may be set aside without a separate or previous judgment establishing the plaintiff's claim and without the issuance and return of execution or similar process." The quoted language is that suggested by the writer for addition to the end of rule $6_{3}(\mathrm{c})$ concerning relief accorded by judgments. A letter from the Secretary to the Committee, under date of February 3, 1937, advises that the proposal was ordered inserted in the rule, the exact place for the insertion and its form being left to a sub-committee. 
lent Conveyance Act represents a codification of the best learning and the best practice under the Statute of Elizabeth, the federal government might well enact such a law to govern in bankruptcy without reference to its adoption in the states. Now that the Uniform Act has been adopted in the entire industrial northeast from New Hampshire to Maryland with the exception of two of the smaller states, ${ }^{8 x}$ and in an unbroken block of states from Michigan to Nevada and Arizona ${ }^{82}$ with Tennessee thrown in for good measure, ${ }^{83}$ and now that its practicality has been affirmatively demonstrated by satisfactory operation covering a period of nearly two decades in several states, ${ }^{84}$ the virtue of the proposal is enhanced. Promoting sound principles of substantive law of fraudulent conveyance, while at the same time promoting uniform state legislation, seems an end justifying far more effort than is involved in the inclusion of the substance of the Uniform Act in the Chandler Bill. It is doubtful if there are any articulate interests that will oppose this aspect of the proposed revision.

\section{PREFERENCES}

The Bankruptcy Act of 1898 includes a fairly comprehensive attempt at definition, ${ }^{85}$ accompanied by an express paragraph providing for the avoidance of preferences. ${ }^{86}$ These provisions specifically cover the period between the petition and the adjudication in a manner that is no longer necessary in view of the systematic manner in which this point is covered by the provisions of the Chandler Bill relating to the title of the trustee. The preference provisions were twice improved and strengthened by amendment, once in $1903^{87}$ and again in 1910. ${ }^{88}$ This branch of the law has suffered, however, from causes other than failure of the legislature to direct its attention to the general subject matter. Basic defects of form in the Act of 1898 remain to cause trouble. Exasperating problems arise out of the defective correlation between the preference provisions and the provisions relating to acts of bankruptcy, ${ }^{89}$ voidable liens, ${ }^{90}$ and the title of the trustee. ${ }^{9 x}$ An amendment in I9Io intimately related to the subject

\footnotetext{
${ }^{8 x}$ New Hampshire, Massachusetts, New York, New Jersey, Pennsylvania, Delaware and Maryland have the Act.

${ }^{82}$ Michigan, Wisconsin, Minnesota, South Dakota, Wyoming, Colorado, Utah, Nevada and Arizona.

$8_{3}$ Citations of the statutes are collected in McLaughlin, op. cit. supra note 76, at $404, \mathrm{n}$. $\mathrm{r}$.

${ }^{84}$ The Act goes back to rgrg in Arizona, Delaware, Michigan, New Hampshire, New Jersey, South Dakota, Tennessee and Wisconsin.

- $\quad{ }^{85}$ Sec. 60 (a). $\quad{ }^{87} 3_{2}$ Stat. 799 (I903); II U.S.C.A. $\$ 96$ (I927).

${ }^{86}$ Sec. 60 (b). $\quad{ }^{88} 36$ Stat. 842 (I9Io); II U.S.C.A. $\$ 96$ (I927).

${ }^{89}$ Sec. $3(a),(b)$.

9r Sec. $70(\mathrm{a}),(\mathrm{e}) ; \S 47$ (a) 2.
} 
matter of preference, incorporated into $\S 47$ of the Act (which relates in general to the duties of the trustee) provisions affecting his status with reference to voidable transactions which properly belonged in an altogether different part of the Act.92 The purpose of this amendment is more effectively achieved by several passages in the Chandler Bill. ${ }^{93}$ It is mentioned here only for the purpose of illustrating how the bankruptcy law in general and the law of preference in particular has suffered from repair services undertaken by people not intimately acquainted with the articulation or with the operation of the bankruptcy machine. An absurd climax to the history of dislocated amendment took place in I926, when, in an attempt to provide against secret transfers too many of which had been achieving immunity in bankruptcy, an amendment to the recording provisions was inserted in the definition of a preference. ${ }^{94}$ Other paragraphs of the law specifically covered the matter of recording with reference both to acts of bankruptcy ${ }^{95}$ and voidable preferences, ${ }^{96}$ so the attempted amendment was altogether abortive. It served only to add to the confusion which was apparently already sufficient to throw the Congress for a total loss. The effectiveness of the law of preference had from the first been materially impaired by strict construction on the part of the Supreme Court in favor of creditors claiming specific securities, whose interest was naturally adverse to that of the bankrupt estate. ${ }^{97}$

Matters of form and of substance are in some degree interwoven, but an attempt may be made to clear the ground by first describing some of the necessary changes in form. One serious cause of confusion particularly troublesome to the student or to the general practitioner who must try a preference case is connected with the fact that a preference is defined not only in terms of a transfer by the debtor, but also in terms of a judgment against him. This raises difficulties of two distinct kinds. In the first place the Act does not mean what it says. It was apparently drawn up by a draftsman who came from a jurisdiction where judgments automatically constitute liens. In the great majority of jurisdictions something further than the docketing of a judgment is required to affix a lien upon personalty, ${ }^{98}$ although it is more common to have a judgment constitute a lien on all the defendant's real estate located in the county where

${ }^{92}$ Sec. 70.

93 See note 69 silpra.

${ }_{95} \mathrm{Sec} .3(\mathrm{~b})$.

9444 Stat. 666 (I926); II U.S.C.A. $\$ 96$ (I936).

${ }^{6}$ Sec. 6o(b).

${ }_{97}$ This criticism applies in greater or less degree to the Supreme Court cases in all the following notes: $114, I_{19-22} \mathrm{I3}^{6-38}$, 140 .

${ }^{88}$ See Hanna, Cases on Creditors Rights ro (1935). 
the judgment is docketed. It is clear settled law that a judgment which does not give rise to a lien is not a preference. ${ }^{99}$

The second kind of difficulty arises from the fact that the subject matter of liens obtained by legal proceedings is more specifically treated in another section of the Act relating to liens. ${ }^{100}$ The most important requisite differentiating a preference by way of transfer from a lien obtained by legal proceedings is the requisite of reasonable cause, on the part of the beneficiary, to believe that a preference is being effected. This, in most instances, turns upon the question whether the transferee or beneficiary has notice of facts which would give rise to a reasonable inference of insolvency. ${ }^{\mathrm{xx}}$ In the absence of such notice, a preferential transfer is indefeasible. The requirement of reasonable cause to believe, however, is altogether dispensed with under the Act of 1898 in specifying the conditions upon which a lien obtained by legal proceedings is voidable. ${ }^{102}$ This difference is reasserted in the Chandler Bill. ${ }^{\text {xo3 }}$ To a considerable extent it can be justified by considerations relating to common business understanding. Reopening closed transactions is not an economical process, and so the more completely a transaction is closed the more restricted the circumstances under which it should be reopened. Payment or satisfaction of a debt is more completely a closed transaction than the creation of a lien, which, while giving rise to a vested property interest, also contains an executory element in that it looks toward the future satisfaction of a debt secured. Pursuing the idea that there is a very definite difference between the character of a payment or satisfaction on the one hand and a security transaction on the other, the writer, at one time, endeavored to persuade the National Bankruptcy Conference to strengthen the law of preference by eliminating the requirement of reasonable cause to believe from all security transactions. The Conference rejected the proposal. That action is probably not to be fairly interpreted as simply a conservative resistance to a change for which the way had not been prepared by sufficient propaganda. It probably expressed judgment or instinct to the effect that a lien obtained without the debtor's consent involves in most or many cases a contentious element absent in consensual transactions, an element which tends to remove it one step farther from a closed transaction. In any event, liens by legal proceedings constitute, both under the

99 Metcalf v. Barker, 187 U.S. I65 (r902). ${ }^{100}$ Sec. 67 (f).

${ }^{\text {rox }}$ To comply literally with the law, it would seem necessary that he have reason to anticipate that bankruptcy would ensue within four months, as that brief period of limitation is one of the basic elements of the preference. No trouble has been caused by a stultifying decision of such unimaginative literalism.

${ }^{102}$ Sec. 67 (f).

${ }^{203} \mathrm{Sec} .67(\mathrm{a})$. 
Act of 1898 and under the Chandler Bill, a type of transaction distinct from transfers by the bankrupt and subject to avoidance under less restricted conditions. The Bill proposes an important simplification of the existing law by referring solely to transfers in its section relating to preferences ${ }^{\mathrm{x} 04}$ and leaving the law of voidable liens by legal proceedings to another section long devoted to that topic. ${ }^{105}$ This change has been accompanied by the elimination of a confusing reference in the specification of acts of bankruptcy to "preference through legal proceedings." A simple statement concerning liens obtained through legal proceedings has been substituted with advantage. ${ }^{\text {.07 }}$

The Bill has usually followed the practice of codifying judicial declarations concerning the meaning of the Act of 1898 that depart from the letter of that Act. The inclusion in the definition of a preference of a requirement that the transfer enable the transferee "to obtain a greater percentage of his debt" than other creditors is misleading. It suggests that it would not be preferential for an insolvent debtor to pay twentyfive per cent of a single debt without making a proportional payment upon other debts, if he were in a position to pay an equal or greater percentage to all other creditors. The law is ${ }^{108}$ and, by the better view, always has been ${ }^{109}$ that such a payment is preferential for the obvious practical reason that the transferee simply credits the payment on account and, unless the transaction is in some way opened up, he comes into bankruptcy and proves for the balance along with other creditors and thus obtains a preferential advantage over them to the extent of practically the whole payment. ${ }^{\text {xxo }}$ Preliminary drafts of the Conference proposals included an express codification of the better rule. The Conference was readily persuaded to do this while the substance of the law was open to doubt by reason of conflicting lower court decisions. ${ }^{\text {IIr }}$ A recent Supreme Court decision, clearly declaring that the Bankruptcy Act does not mean what it would appear to the casual reader to say, ${ }^{\mathrm{Yr} 2}$ has been, unfortunately,

I04 Sec. 60. $\quad{ }^{105} \mathrm{Sec} .67 . \quad{ }^{106} \mathrm{Sec} .3(2) 3$ of the Act of 1898.

${ }^{107}$ Sec. $3(a) 3$ of the Bill is a consolidation of the third and fourth acts of bankruptcy.

${ }^{308}$ Palmer Clay Products Co. v. Brown, 297 U.S. 227 (1936).

${ }^{109}$ See McLaughlin, op. cit. supra note 30 , at $38 x$.

so His exact advantage would be determined by subtracting from the payment the share of it coming to him if the payment be restored and distributed ratably among all creditors having provable claims.

ir See 4 Remington, Bankruptcy 589-9r, 597-604 (3d ed. x923). Commerce-Guardian, etc. Bank v. Devlin, 6 F. (2d) 518, 519 (C.C.A. 6th I925); Eyges v. Boylston Nat'l Bank, 294 Fed. 286, 288 (D.C. Mass. I923).

${ }^{25}$ See note ro8 supra. 
taken by the Conference as sufficient reason for refusing to depart from the existing statutory language on this point. This action of the Conference is nevertheless intelligible because a more or less cumbersome circumlocution seemed necessary to avoid the present language. ${ }^{1 \times 3}$

In Martin v. Commercial National Bank ${ }^{\mathrm{xx}}$ an old chattel mortgage was recorded the day before bankruptcy, the mortgagee then having knowledge of the debtor's insolvency. Unrecorded chattel mortgages were void against liens obtained prior to record. ${ }^{\text {Irs }}$ Since the property apparently remained in the bankrupt's possession it came "into the custody of the bankruptcy court" so as to give the trustee the status of one "holding a lien obtained by legal or equitable proceedings," under the Bankruptcy Act. ${ }^{\text {Ix }}$ The Bankruptcy Act, after defining a preference in terms of a transfer made within a period of four months before bankruptcy, goes on to provide that "such period of four months shall not expire until four months after the date of the recording . . . if . . . such recording . . . . is required. . . " " II7 It further provides that the elements of a voidable preference such as insolvency and "reasonable cause to believe" that a preference is being effected shall be tested upon the date of recording, if recording is required. ${ }^{\mathrm{rr}}$

The intention to defeat transfers such as that in the Martin case seems clear. The recording act protects lienholders. The trustee is a lienholder. The validity of the transfer is to be tested as of the date of the recording, not of the transfer. Secret liens first made public during insolvency and with notice thereof are to be vulnerable for a period of four months. Unfortunately, a technical flaw appears. The recording act does not protect lienholders who become such the day after the recording, and although it may be urged that the Bankruptcy Act discloses a clear intention to let the trustee reach back for four months under the circumstances, it does not say so in so many words. Accordingly, the Court held that recording was not required to defeat the claim of a subsequent lienholder such as the trustee. Even on the most literal basis it would seem admissible to urge that, since a day's further delay in recording would have permitted the trustee to prevail, recording certainly was most emphatically required as to him. Since, however, the Supreme Court has consistently

${ }^{1 \times 3}$ The circumlocution is due to the fact that a payment by an insolvent to a creditor is not preferential if accompanied by payments of a like percentage to other creditors (an unusual informal adjustment), or if contemporaneous provision is made for insuring such a percentage to creditors, as by an assignment for the benefit of creditors.
${ }{ }^{14} 245$ U.S. 513 (I9I8).
${ }^{116} \operatorname{Sec} .47(a) 2$.
${ }^{\mathrm{rr} 8}$ See 6o(b).
${ }_{215}$ Under Ga. Code rg1o, $\$ 3260$.
${ }^{x 7} \mathrm{Sec} .60(\mathrm{a})$. 
evinced an inclination to favor the secured creditor by such strict constructions the only remedy, if any, lies in legislation. As things stand the trustee is held to be altogether outside the protection of the recording acts in the great majority of cases of tardy recording before bankruptcy. Indeed, the Supreme Court has gone further and, altogether unnecessarily it would seem, recognized fictions of relation back under state law whereby a tardy perfection of a transfer validates it as of an earlier date such as the date of the execution of the instrument of transfer. ${ }^{\text {Irg }}$ All decisions to such effect are intended to encounter as flat a contradiction in the Chandler Bill as statutory English permits.

How great a step to take with particular reference to the status of the trustee has been the subject of repeated and extensive debate in the Conference. The Chandler Bill has not embraced the solution perhaps most obviously suggested by the Martin case-to give the trustee the status of the holder of a lien antedating bankruptcy by four months. That would give him an undesirable seniority over bona fide transferees. The solution proposed is a simple declaration that, for the purpose of avoiding preferences, a "transfer shall be deemed to have been made at the time when it became so far perfected that no bona fide purchaser from the debtor and no creditor could thereafter have acquired any rights in the property so transferred superior to the rights of the transferee." It will be observed that by giving the trustee the status of a bona fide purchaser he is brought within the protection of the common real estate recording acts, thus reversing not only the Martin case and like cases ${ }^{120}$ but the leading case of Carey v. Donohue, ${ }^{\mathrm{I2x}}$ which arose on a Georgia real estate statute. Furthermore the phrasing is not limited to secret liens within the recording acts. It is broad enough to cover analogous cases such as those were a judge-made "equitable lien" is invoked to save secret transfers invalid for failure to take the steps essential to a valid transfer at common law. ${ }^{122}$ Although the decision to give the trustee the status of a bona fide purchaser is a more radical one than was proposed in the original draft of this section of the Chandler Bill propounded in $1927,{ }^{123}$ the

19 Thompson v. Fairbanks, 196 U.S. 516 (1905); Humphrey v. Tatman, 198 U.S. 9I (1905).

r2o Bailey v. Baker Ice Machine Co., 239 U.S. 268 (19r5), taken with the two cases named in the text, completes the trio of leading cases. A conditional vendor there prevailed.

240 U.S. 430 (I9I6).

Iaz Sexton v. Kessler \& Co., Ltd., 225 U.S. 90, 97 (19I2); Hurley v. Atchison, etc. Ry., 213 U.S. I26 (I9og); In re Heyward-Williams Co., 284 Fed. 983, 987 (D.C. Ga. I922); Mass. Trust Co. v. Macpherson, I F. (2d) 769 (C.C.A. Ist 1924).

${ }^{23} 3$ See McLaughlin, op. cit. supra note 30 , at 377. 
step is less drastic than that apparently approved in principle by Congress in passing the abortive amendment of 1926 with reference to preferences. $^{\mathrm{I} 24}$ If the transfers were not to become indefeasible by lapse of time in cases where recording was merely permitted by loose local practice in recorders' offices, transactions might have been amenable to attack by the trustee during an indefinite period, even when such transactions were not amenable to attack by bona fide purchasers because not required to be recorded in order to have validity against such purchasers. The new proposal, thus, in effect substitutes a clear-cut test of when an instrument is required to be recorded for the nebulous test of permission to record, which would have had an uncertain operation in many states and which would have more grievously failed to have a uniform operation throughout the United States. The Chandler Bill, while following the established system under the Act of 1898 in that the validity of an alleged preference frequently involves reference to state statutes and hence has no uniform operation in fact, still has the advantage of a clear-cut federal criterion with reference to which the operation of the state law may be tested.

The Bill further has the strength and weakness of a single crisp revision covering a multitude of situations. The $x_{927} 7$ precursor of this paragraph contained, for instance, a separate paragraph upon the topic of floating liens. ${ }^{\text {I25 }}$ This paragraph, along with various other attempts to spell out particular situations, was eliminated in the Conference, pursuant to the general theory that the statement of one detail invites another and that bankruptcy laws should not undertake detailed codification concerning business transactions. The result is, to some extent, open to the objection that existing business practices in certain lines may be seriously affected by the difficulty or the impossibility of providing by contract or conveyance for a lien upon after-acquired property which will be indefeasible if bankruptcy ensues within four months after the acquisition of the property. Various considerations may be offered in mitigation of this objection. There is nothing in the Chandler Bill to require the abrogation of clearly established specific doctrines of the law such as the doctrine of accession which provides that title to the foal shall follow title to the dam. ${ }^{126}$ Chattel mortgages upon cotton crops, which loom so large in the South, would seem to be generally within the scope of recording acts protecting the holder of a recorded instrument against all subsequent purchasers or lien claimants, ${ }^{127}$ and by the majority rule, a valid lien may

\footnotetext{
124 See p. $3^{89}$ supra. ${ }_{225}$ McLaughlin, op. cit. supra note 30 , at 379,387 .

${ }^{226}$ Bryan v. Weems, 29 Ala. 423 ( 1856 ).

${ }^{227}$ See I Williston, Sales 259 (2d ed. I924).
} 
so arise before the crop is planted. ${ }^{128}$ Even in Georgia, where prior planting is required, exceptions have been and may be made to mould the state law in accordance with business convenience. Thus a statutory lien for fertilizer has there been held, in the absence of express provision, to be valid when the instrument is executed before planting, for the obvious reason that the main use for fertilizer arises at the time. ${ }^{129}$ It may further be remarked that the effect of bankruptcy upon security transactions may be easily exaggerated, since only a small percentage of insolvencies actually lead to administration in the bankruptcy courts.

A final suggestion concerning this point may be offered to the effect that, if the proposed law of preference should actually operate adversely to the public interest in any state, the defect may be readily cured by state legislation. The section relating to liens specifically states:

the provisions of section 60 of this Act (the preference section) to the contrary notwithstanding, statutory liens in favor of employees, contractors, mechanics, landlords or other classes of persons .... created or recognized by the laws of the United States or of any state, may be valid against the trustee. . . . ${ }^{\mathrm{x} 30}$

There is said to be some tendency for state legislatures to multiply statutory liens with a view to giving advantages to local creditors. ${ }^{\text {III }}$ If such practices increase, it may be necessary at some future time to restrict the generality of the foregoing language. At present the language stands as a codification of existing law which affords a safeguard against any unduly burdensome effects of section 60 . The Conference has adopted the view that a distinction may fairly be made between statutory liens deliberately adopted as the policy of a state and judge-made "equitable liens," ${ }_{322}$ which fly in the teeth of the true principles of equality and equity embodied in the bankruptcy law. These last would seem to be most uncompromisingly extinguished if the Chandler Bill is enacted.

\section{STOCKBROKER'S BANKRUPTCY}

One codification relating to a special type of business transactions has been embodied in the Bill. Skepticism concerning the value of the complicated supposed equities traced in stockbrokerage bankruptcy was ex-

${ }^{228}$ Williston, op. cit. supra note $\mathrm{r} 27$, collects authorities for the majority rule including cases from Alabama, Mississippi and both Carolinas.

r29 Hardwick v. Burtz, 59 Ga. 773 ( 1877 ). Williston, op. cit. supra note 127 , collects statutory limitations upon crop liens including Alabama, Arkansas, Georgia and South Carolina statutes to that effect, such as limiting their validity to crops grown or to be grown in the calendar year.

${ }^{{ }^{3} 30}$ Sec. 67(b).

${ }^{13 x}$ This suggestion was raised in the Conference by a member from the far Northwest.

${ }^{232}$ See note I22 supra. 
pressed by Judge Rose in $1923^{\mathrm{r} 33}$ and echoed in a bankruptcy periodical two years later. ${ }^{134}$ Probably the first draft amendment designed to achieve the desired ends was formulated in $1927 .{ }^{\mathrm{I} 35}$ The Chandler Bill has retained the essential idea of this proposal. The result of each of the leading Supreme Court cases in the field is to be reversed. Contrary to the rule of Richardson v. Shaw ${ }^{{ }^{3} 36}$ a transfer of securities by an insolvent stockbroker to a customer may be preferential, because the customer is considered a creditor within the meaning of the definition of a preference applicable to stockbrokerage bankruptcy. Contrary to Gorman v. Littlefield ${ }^{\mathrm{x} 37}$ and to Duel v. Hollins ${ }^{\mathrm{r} 38}$ shares of the stock of each corporation are not to be treated separately, but all of the securities involved in the stockbroker's transactions with his customers are to constitute a single fund, except those actually allocated to or physically set aside for a particular customer at the time of their receipt or acquisition, or at any subsequent time while the stockbroker was solvent. The 1927 proposal included a proviso giving priority to customers whose securities had been "wrongfully pledged, repledged or converted" "not because of any firm conviction as to its inherent soundness, but because it seems to be in line with settled law which need not be changed to effect the main purpose of the proposed amendment." ${ }_{339}$ The elimination of this proviso removes the proposal even farther from the doctrines developed under the fourth leading Supreme Court case of Thomas v. Taggert ${ }^{\mathrm{T} 40}$ where a customer was given a lien to compensate him for the conversion of his margin.

An effort was made in the Conference to procure the advice and the collaboration of referees and attorneys who had had substantial practical experience in the administration of the estates of insolvent stoclsbrokers. Contary to the usual result when academic proposals are submitted to practical groups, the character of the changes introduced became more, rather than less, radical. The misgivings suggested in 1927 concerning the soundness of the existing distinctions between the so-called class A and class B customers, entitled to payment in the alphabetical order of those letters, deepened to the conviction that the existing distinctions pursuant to which the customers are so classified are absolutely indefensible. An

${ }^{233}$ See In re Archer Harvey \& Co., 289 Fed. 267, 272 (D.C. Md. 1923).

${ }^{{ }_{34} 4}$ See Moses, Stock Brokerage Bankruptcies, I Am. Bkcy. Rev. 202 (I925). Mr. Moses seemed to assume that, the Supreme Court having spoken, the situation must be tolerated indefinitely. Modification of the statute was not discussed.

${ }^{235}$ See McLaughlin, op. cit. supra note 30 , at 378.

${ }^{{ }^{36}} 209$ U.S. 365 (I908). $\quad{ }_{37} 229$ U.S. I9 (I9I3).

${ }^{239}$ See McLaughlin, op. cit. supra note 30 , at 384 .

${ }^{x 38} 24$ I U.S. 523 (I9r6).

$14^{\circ} 209$ U.S. 385 (IgO8). 
attempt to draw the line in such a position as greatly to reduce membership in class A was found to present virtually insuperable practical difficulties. Discussion of business practice and understanding with reference to different classes of customers developed the obvious idea that any customers not paid in full have a justification for feeling abused upon the stockbroker's insolvency. The broker breaks faith even with the marginal customer who has expressly permitted his securities to be repledged if the broker does not redeem them on demand. Even the so-called "cash" customer who delivers his security for sale to the broker and gets caught in a "last day transaction" has in fact trusted the general credit of the broker when he has not insisted upon the instantaneous payment of cash against delivery and when he has taken no steps to see that the proceeds of his transaction are segregated. The fact that many brokers would not bother with a customer who made such unusual requests merely means that it has become customary for persons dealing with stockbrokers to allow the stockbroker to throw their securities and money into a common pot. Hitherto, some of them have successfully relied upon the courts' fishing substituted res out of the pot for them when all physical identity has been lost.

If one approaches the stockbrokerage business from the point of view embodied in the maxim that "equity regards that as done which ought to be done," the most exquisite subtleties of which the human mind is capable may be invoked to create specific individual rights in rem out of the mess which the stockbroker has brewed. If one approaches the same situation from the point of view embodied in the equitable maxim that "equality is equity," a democratic maxim concerning which the bankruptcy courts have remained better informed than the chancellors themselves, one arrives at the conclusion that general credit is general credit even if expected to endure only for a brief period. As Mr. Justice Holmes vividly said where a bank was caught upon a last day clearance loan which involved "consent to become a general creditor for an hour":

Time sometimes can be ignored when it is insignificant, but in this case the time between the loan and the transfer of securities sufficed to change the position of the borrowers from a fortune of half a million to a deficit of double that amount. ${ }^{14 \mathrm{I}}$

-If one approaches the problem from the point of view of customers, it is indisputable that the different degrees in which different customers trust the broker run through such a wide range that many possible distinctions might logically be taken. At the same time it is abundantly clear that the existing law turns upon refinements utterly unintelligible to

I.I Nat'l City Bank v. Hotchkiss, 23I U.S. 50, $5^{8}$ (Igr3). 
the business man and involves elements of chance more appropriate to a beano party than to the administration of justice. If the problem be approached from the point of view of ease and economy of administration, the solution of the Chandler Bill warrants a high rating. Apart from weaknesses that may lurk in the imperfections of draftsmanship inevitably to be suspected when attempt is made at a partial codification of law governing complicated commercial transactions, the Bill is probably most vulnerable to temperate criticism from the point of view of those who would insist upon priority for cash customers who are diligent in seeing that their cash transactions are executed. As Mr. Glenn has sagely remarked, however, any reasonable man ought to know that a broker's office is no place to leave money or securities for safe-keeping. ${ }^{\mathbf{1 4 2}}$

\section{BANK SET-OFFS}

A proposal made ten years ago with reference to set-offs in bankruptcy ${ }^{\mathrm{T} 43}$ has been incorporated in the Chandler Bill, not without debate, but without substantial modifications. It includes an express prohibition against the preferential acquisition of a set-off by means of a loan from the debtor to a creditor under such circumstances that a payment of the creditor's debt would constitute a voidable preference. The impropriety of such a transaction, which in a clear case would differ in only the most superficial formal respects from a payment, is so obvious that only considerations of symmetrical form and completeness would suggest its inclusion in the Chandler Bill, were it not for the fact that the courts do not seem to have been sufficiently alert to observe how bank deposits have frequently partaken of the nature of such preferential transfers. This defect in the existing law concerning bank set-offs is sufficiently serious to call for a separate treatment in the Bill. The fountainhead of the undesirable judicial practice is New York County National Bank v. Massey. ${ }^{144}$ In that case a deposit was built up from $\$ 218.50$ four days before bankruptcy to a sum $\$ 6225.25$ greater on the eve of bankruptcy. One $\$ 16$ check was honored by the bank in the interim. Perhaps it is necessary to accept the Court's conclusion that the deposits were made in the usual course of business. Doubt is cast upon the meaning of this statement, however, by more questionable statements included in the opinion. Mr. Justice Day made the broad and unqualified declaration that "a deposit of money to one's credit in a bank does not operate to diminish the estate

${ }_{142}$ Discussing $\S 60(\mathrm{e})$ of the Bill at the Commercial Law Round Table of the Association of American Law Schools in December, 1936.

I43 McLaughlin, op. cit. supra 30, at 604 .

${ }^{144} I_{92}$ U.S. $\mathrm{I}_{3} 8$ (IgO4). 
of a depositor." Since the preferential payment of a debt never diminishes the algebraic difference between assets and liabilities, diminishing the estate would seem to be an irrelevant consideration. If the statement means that the deposit never operates to give the bank a questionable advantage over other creditors, it is manifestly false. The learned justice further said that such a deposit "is not a transfer of property as a payment, pledge, mortgage, gift, or security." ${ }^{45}$ If this statement be accepted as the authoritative announcement of a judicial fiction, it may still be abrogated by legislation if it leads to undesirable results. If it is intended as a simple declaration of a fact, it is manifestly false. Perhaps the least illustrious of the offspring of the Massey case best illustrates the vice of the doctrine there announced. In Continental Bank v. Chicago Title and Trust Co., ${ }^{\mathrm{x} 46} \mathrm{a}$ bank, well knowing a depositor to be insolvent, accepted from him $\$ 3000.00$ for the express special purpose of meeting his pay rolls and his checks to a board of trade clearing house. Upon discharge of this function, the bank was permitted to appropriate to the payment of its claim a $\$ 575.00$ balance remaining in this special account.

There are some obvious facts with which it is necessary to deal. Setoffs between solvent parties are advantageous as being economical and in accord with common business practice and understanding. Long standing practice and commercial expectancies also are consistent with the extensive recognition and application of set-offs in insolvency proceedings, unless the set-offs have been in some way manipulated or planned with a view to the payment or security of an antecedent debt during insolvency. The peculiar difficulty presented by a bank account is that there is no criterion that can even be formulated, much less any that can be infallibly applied, to designate just when a deposit is a mere change in the form of the depositor's liquid assets and when it is a transfer by way of security to the bank, to whom the depositor is indebted. There may be many cases in which the depositor does not stop to contemplate that the bank may suddenly exercise the right to apply his balance upon his notes, which usually contain an express authorization to take that action at any time. There may be cases in which a bank, having reasonable cause to believe that the depositor is insolvent, still intends to permit the entire deposit to be paid out and to refrain from exercising its power of set-off, an exercise which the duty of the bank managers to the bank stockholders would generally tend to make prima facie desirable. If such a bank be deprived of the privilege of changing its mind, it comes off no worse than it may reasonably expect. If, on the contrary, it be granted the privilege

145 Id. at I47. 146229 U.S. 435 (19r3). 
of changing its mind with the inducement of acquiring an advantage over other creditors by appropriating the deposits received after notice of insolvency, we should not be surprised to find bankers exhibiting an almost uniform behavior pattern involving a peculiar mental vacillation. It may be predicated that the nature of this change of intention has a high degree of correlation with the financial interests of the bank. And where, as must frequently be the case, a bank receives deposits from an insolvent with reasonable cause to believe that he is insolvent and with the intention of seeing that a whole or a large part of such deposit is applied to the depositor's debts to the bank before it is checked out, the assertion that a deposit is not a transfer by way of security to the bank becomes utterly absurd. In view of the difficulty of getting reliable evidence concerning the precise attitude of the parties, it seems reasonable to assume that, in the normal case, the bank knowingly receiving deposits from an insolvent will contemplate action in accordance with the first law of nature. Is it too much to ask in addition that banks be held to the standard usually applied in commercial law? A person is usually charged with notice of facts which would appear to the intelligence of the ordinarily prudent man. ${ }^{\mathrm{x}} \mathrm{x}$

Even if the Bill embodies no unjust sacrifice of the interests of bankers it may still be open to other objections. What may be the practical consequences of modifying this aspect of the law of security transactions? ${ }^{\times 4^{8}}$ The less the secured creditor is favored the more careful he may be expected to be in the granting of credit. ${ }^{149}$ A commercial society can survive under a wide range of legal provisions. Canada has, for instance, been careful to provide specifically for security to banks $\mathrm{s}^{\mathrm{I5}}$ and particularly to specify that the right and privileges conferred under the Banking Act are not impaired by the Bankruptcy Act. ${ }^{\text {I5I }}$ The natural tendency has been to encourage bank credit at the expense of other sources of credit. Parenthetically, the question may be raised as to how far the satisfactory opera-

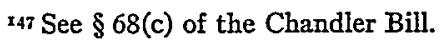

${ }_{x_{4}^{8}}^{8}$ In Studley v. Boylston Bank, 229 U.S. 523, 529 (1913), Mr. Justice Lamar used strong language concerning the disastrous effects on credit if banks were deprived of their established rights of set-off. In that case, however, the bank would have prevailed if the Chandler Bill had been in force, as at the time the deposits were made, it had no reasonable cause to believe that a preference would be effected. The attack attempted on the transaction there was based on the irrelevant fact that the set-off was effected by the bankrupt's check rather than by an appropriation of the deposit by the bank.

${ }^{49}$ See p. 37 I supra.

${ }^{250}$ See Can. Stat. I934, c. $24, \$ \S 76,77,86-89$; Can. Rev. Stat. I927, c. II, $\$ 67(2)$.

${ }^{I 5 \pm}$ Can. Rev. Stat. I927, c. II, $\$ I 89$. 
tion of the Canadian system is tied up with a highly centralized and rigidly regulated banking system. In any event, American law has not developed along the Canadian lines. The present question is whether national interests in the promotion and control of credit require or suggest that banks be given, by judicial leniency under our existing system, advantages as creditors which the ordinary principles of equity as between man and man would indicate to be unfair and preferential. The question may reasonably be answered in the negative. If the Chandler Bill becomes a law, a bank may be less inclined to allow a debtor to procrastinate after the bank receives notice of the debtor's insolvency. Instead of taking a chance on waiting until the next deposit comes in, it may elect to appropriate the bank account as soon as the insolvency is known. It does not follow from this, however, that the crop of bankruptcies or irredeemable failures will increase. Ordinarily both bankers and commercial creditors share a desire to preserve rather than to cripple a customer. There is widespread commercial opinion, as well as opinion in the National Bankruptcy Conference, to the effect that more is lost than is gained by permitting insolvents to become deeply involved without a reckoning. ${ }^{152}$ If the bank's power to draw in for appropriation all the liquid assets on the eve of bankruptcy is impaired, it may be moved to take action which will call for the intervention of a creditor's committee at an earlier stage of the operations of a failing debtor than under the present practice. There is no reason why action leading to the enlightenment of creditors should produce more catastrophes than it eliminates. The suggestion that our economy has suffered more from excessive credit than from deficient credit is not a novel one. With specific reference to the existing situation, it is submitted that bank attorneys objecting to the set-off provisions of the Bill have not yet made out a case.

\section{POLITICAL PROGNOSIS AND PARTHIAN PRAYER}

It will be interesting to follow the political history of the Chandler Bill. A very large percentage of the amendments in it have chiefly to contend with inertia. Technically sound, they contain nothing of political interest much less any political dynamite. In a minority of instances, where par-

25* See Sadd and Williams, Causes of Commercial Bankruptcies, U.S. Dept. of Com., Dom. Com. Ser. No. 69, p. 7 (r932); Douglas, Bankruptcy, 2 Encyc. Soc. Sci. 453 (1930). Cf. Webster, op. cit. supra note 7 .

For recent angles on the eternal fight between sales and credit departments see Zimmerman, Sales and Credit Hook-up, Printers' Ink $4 \mathrm{x}$ (Dec. I7, r936); Credit and Financial Management 9, 42 (Jan. 1937). Some merchants are trying to make salesmen out of credit men. See Dry Goods Economist II (June 23, I936); Bonner, Building Profitable CustomerContacts, Credit World 26 (Feb. I937). 
ticular articulate interests have been weighed and found wanting, the situation eludes such simple analysis. Within the Conference itself, it appeared for a time as if the forces of negation would win. If everyone who found a provision that he did not like would refuse to support the Bill until the provision was eliminated, a product would result whose innocuousness would be exceeded only by its insignificance. But, as the technical horrors of the existing law were repeatedly contemplated, a less pettifogging spirit prevailed.

The fact that the Bill's technical soundness is vouched for by specialists in a highly specialized field may appeal to a Congress composed of members most of whom would really like to do the right thing, if their constituents would let them. The general effect of the competent use of legal English cannot be altogether lost upon the lawyers in that assembly. At the meetings of legal societies in Boston last summer, a minority view was expressed to the effect that Congress would have none of a Bill which does something for everyone except the farmer. ${ }^{\text {I53 }}$ There is, however, nothing in the Bill which in any way detracts from discriminations already made in favor of the farmers. ${ }^{54}$ As long as Uncle Sam strenuously exerts himself in the special interests of the farmer from time to time and since he may be relied upon to do so at least as long as the over-representation of agrarian interests in the Senate persists, it may not be too much to hope that a bill will be tolerated which only gives the farmer so much advantage as he may share in common with all other citizens by reason of a sound reconstruction of an act intimately connected with our credit structure. Possibly if some agrarian Senator wants to know what there is in it to please his people it may be suggested that some of the bank lawyers do not like it. If proposals of the Securities and Exchange Commission concerning corporate reorganization can be incorporated over the objections of the reorganization bar, the Bill may acquire new enemies of such eminence that its popularity will be insured. Is it too much to ask of our age that a new Daniel Webster arise in the Senate, master the Chandler Bill with its economic implications and carry it through by sheer force of intellect? To the like of such a legendary leader might be safely entrusted the manipulation of even that most dangerous accessory of democratic government, the "amendment on the floor."

${ }^{x 53}$ At the forum under the auspices of the Committee on Commercial Law and Bankruptcy of the American Bar Ass'n, Aug. 26, 1936.

${ }^{154}$ The Bill purports only to amend certain sections (a majority) of which $\$ 75$-Agricultural Compositions and Extensions" is not one. The immunity of farmers from involuntary bankruptcy is not disturbed. $\S_{4}(\mathrm{~b})$. 